\title{
Collecting and Managing Wild Malus Germplasm in its Center of Diversity
}

\author{
Stan C. Hokanson', James R. McFerson, Philip L. Forsline, and Warren F. Lamboy \\ U.S. Department of Agriculture, Agricultural Research Service, Plant Genetic Resources Unit, Cornell University, \\ Geneva, NY 14456-0462 \\ James J. Luby \\ Department of Horticultural Science, University of Minnesota, St. Paul, MN 55108
}

Aimak D. Djangaliev

Kazakstan Academy of Sciences, Almaty 480064, Kazakstan

Herb S. Aldwinckle

Department of Plant Pathology, Cornell University, Geneva, NY 14456-0462

\begin{abstract}
Few images seem more "American" than a golden-crusted apple pie steaming on a kitchen table, the teacher's apple, or refreshing apple cider. Furthermore, the aphorism "an apple a day keeps the doctor away" is one of the tenets of American folk medicine. Springing from the deep culture that developed out of America's love for the apple (Malus domestica Borkh.), many of us as schoolchildren first learned about plant genetic resources via the story of Jonathan Chapman, better known as Johnny Appleseed. Chapman (1744-1847), arguably America's first germplasm manager, spent years wandering between pioneer outposts distributing and planting apple seeds. The lesson was simple: to have edible domesticated apples and cider on these new frontiers, settlers had to bring their own germplasm. As with most crops the European settlers depended on, domesticated apples were not native to North America, although native crabapples are abundant. In fact, this quintessential "All-American" fruit should more aptly be called the "All-Central Asian" fruit, since the domestic apple originated in the region that is now known as the Republic of Kazakstan, from where it has subsequently spread throughout the world.
\end{abstract}

The genetic base of apple has changed dramatically over time. Where thousands of local or regional types, fixed by clonal propa-

\footnotetext{
Received for publication 15 July 1996 . Accepted for publication 26 Sept. 1996. We thank Frank Dennis, Ned Garvey, James Hancock, Jules Janick, and Stephen Krebs for their prompt and thoughtful reviews of this manuscript; Richard Soper and Eric Rosenquist of the U.S. Dept. of Agriculture (USDAARS) Office of International Research Programs for their support; and Allan Stoner of the USDA-ARS National Plant Germplasm System for his sustained interest. Finally, we acknowledge the foresight and initiative of the late Calvin Sperling, whose efforts laid the foundation for our collaborative effort. This work was supported in part by funding through USDA-ARS Specific Cooperative Agreement 580500-4-F100. The cost of publishing this paper was defrayed in part by the payment of page charges. Under postal regulations, this paper therefore must be hereby marked advertisement solely to indicate this fact.

${ }^{1}$ To whom reprint requests should be addressed; email: sch10@cornell.edu.
}

gation, were once the norm, today's commercial market is dominated by a limited range of cultivars meeting specific consumer, grower, and retail preferences. Thus, genetic diversity in the cultivated apple has been continually eroding from a point when more than 7000 commercial cultivars had been described (1804-1904) to the present, when most of the world's production is based on two cultivars: 'Delicious' and its red sports, and 'Golden Delicious', with present expansion based on their seedlings- 'Gala', 'Mutsu', 'Jonagold' from 'Golden Delicious' and 'Empire' and 'Fuji' from 'Delicious' (Janick et al., 1996). Exacerbating this decline in genetic diversity is a diminution of breeding programs (Brooks and Vest, 1985). This decline has occurred in spite of the steady incursion of new insects and diseases and the growing worldwide demand for improved cultivars with higher quality and resistance to biotic and abiotic stresses. Worldwide apple production has more than doubled since 1970 , from $\approx 21$ to $\approx 49$ million tons in 1995 (FAO, 1996).

To meet future demands for Malus genetic resources, a national effort was initiated in 1979 by the U.S. Dept. of Agriculture-Agriculture Research Service (USDA-ARS) to develop germplasm repositories for apples, as well as other fruit and nut crops (Brooks and Barton, 1977). Nearly 20 years later, nine such repositories exist, among them the Plant $\mathrm{Ge}-$ netic Resources Unit (PGRU), which manages one of the world's largest Malus germplasm collections. The unit, located on Cornell Univ.'s Geneva campus, is a part of the USDA-ARS National Plant Germplasm System (NPGS). All such repositories were established to acquire, maintain, characterize, document, and distribute the genetic resources of their assigned crops. More than 2500 Malus germplasm accessions are maintained as trees in PGRU orchards, with an additional 700 accessions of wild Malus species stored as seed or maintained as seedlings in the field. Each year $\approx 3000$ Malus accessions are distributed to researchers worldwide.

The USDA-ARS Malus collection was established mainly with materials from contemporary breeding programs and was biased toward immediate commercial or breeding utility, rather than genetic diversity per se. In addition, accessions were not uniformly documented, thus significant duplications and misclassifications became apparent. In 1992, apple curator $\mathrm{P}$. Forsline and the Malus Crop Germplasm Committee (CGC) identified 300 duplicate or redundant accessions; these were removed from the collection (Forsline and Way, 1993). At the same time, P. Forsline and the CGC worked with the late Calvin Sperling, USDA-ARS botanist, to identify gaps in germplasm holdings, primarily in wild germplasm. They found some species (total species estimates for Malus range from 25 to 36) were represented by a single accession and/or had scant passport information, primarily because most Malus wild germplasm is native to Central Asia and China, areas that until quite recently had been nearly impossible for U.S. scientists to visit.

The under-representation of wild germplasm, particularly from the apple's center of origin, was critical because such material would likely contain more genetic diversity for such important traits as disease and insect resistance, fruit quality (texture, aromatics, storage life), growth attributes (suckering, vigor, tree architecture), and physiological characters (juvenility, chilling requirement, dates of flowering and fruit maturation), along with a wide array of genes that might later prove useful in solving unforeseen problems (Korban, 1986; Way et al., 1991). In addition, access to previously unobtainable wild germplasm would allow our knowledge regarding the origin and domestication of the modern apple to advance, along with increasing our understanding of the genetic diversity of wild Malus populations. Determining the manner in which genetic diversity is structured in such populations would allow for efficient collection strategies to be devised and meaningful in situ germplasm management plans to be developed (Brown and Marshall, 1995; Epperson, 1990).

The domesticated apple is a complex hybrid of several Malus species. $M$. sieversii (Ledeb.) M. Roemer is the predominant species, but other species that have probably contributed genes include the wild Caucasian apple ( $\boldsymbol{M}$. orientalis Uglitzk), as well as crabapples from Europe (M. sylvestris Miller), Siberia [M. baccata (L). Borkh.], Manchuria [M. mandshurica (Maxim) V. Komarov], and 


\section{GERMPLASM EXPLORATIONS}

China [M. prunifolia (Willd.) Borkh.]. Wherever $M$. sieversii occurred sympatrically with the other species, hybridizations could have occurred, leading to the introgression of genes of the secondary species. Humans probably facilitated (and/or further complicated) the process by selecting superior forms and moving them as sexually and asexually propagated material along trade routes, such as the Silk Road, over thousands of years.

Wild $M$. sieversii occurs from the Tien Shan mountain range on the border between China and Kazakstan, Kyrgyzstan and Tajikistan, to the edge of the Caspian Sea. The species shows its greatest diversity in Kazakstan around the city of Almaty (formerly Alama Ata), which appropriately translates as "Father of Apples." The great Russian plant explorer and geneticist Nikolai I. Vavilov considered this the center of origin for cultivated apple and described a full range of morphological variation in local forests: "Wild Kazakstan apples are mostly represented by large-fruited varieties approximating cultivated apples, which makes them different from Caucasian ones with small fruits... Some of the wild forms were so good regarding both fruit taste and size that they might be merely removed to an orchard" (Vavilov, 1987). In the Tien Shan range, whole valleys are forested with apple trees, the beauty of which prompted the travel writer V. Vitkovich to write in 1960: "This was life in a marvelous garden of wonders such as are described in fairy tales, a marvelous garden where apples and pears look down on you from the trees and beg to be eaten, where a magic wind brings you showers of nuts, where birds are radiantly feathered and animals trustful and the imprints of bear's paws are to be seen on the paths" (Morgan and Richards, 1993).

With the dissolution of the Soviet Union, the possibility arose of traveling to these regions of fabulous genetic wealth for Malus. In 1988 , C. Sperling and A. Djangaliev initiated the current project. A. Djangaliev has spent his career studying Malus species in the region and has authored several books in Russian on wild fruits and apple (Djangaliev, 1977). These initial contacts were formalized with the assistance of the Office for International Cooperation and Development, and a USDA Specific Cooperative Agreement was established to identify, collect and measure genetic diversity in wild Malus populations, with germplasm to be shared equally between Kazak and U.S. researchers. In addition, the project was designed to develop more secure in situ reserves of wild Malus to complement ex situ holdings in the United States and Kazakstan. Finally, the agreement also provides for the English translation of two of A. Djangaliev's most important writings: "The Wild Apple Tree of Kazakstan" and "Wild Fruits of Kazakstan." To date, three collection expeditions to the Kazakstan region have included participants from seven research institutes and universities. In addition, four Kazak scientists were funded to tour NPGS sites, exchange information, and collect germplasm in the United States.
The first trip to Central Asia, in 1989, was led by $\mathrm{H}$. Aldwinkle and included C. Sperling and Elizabeth Dickson (Dept. of Horticultural Sciences, Cornell Univ.). Seed of 114 Malus accessions was collected in Uzbekistan,

After the cooperative agreement was approved, P. Forsline organized a second expedition in 1993 with additional participants: E. Dickson, Gaylord Mink, Dept. of Plant Pathology, Washington State Univ., Pullman, and Dominique Noiton, Geneticist, Dept. of Scientific and Industrial Research, Fruit and Trees, Havelock North, New Zealand. Despite a severe spring frost, which left only $5 \%$ of the trees bearing fruit, 129 accessions were collected, representing 16 genera and 24 species. Malus collections included 65 accessions (18,000 seeds) representing three endemic species and scions from five horticulturally superior trees.

Material collected during the 1989 and 1993 trips has already shown interesting diversity for disease resistance. Greenhouse screening of 1600 seedlings in $\mathrm{H}$. Aldwinckle's laboratory for resistance to apple scab [Venturia inaequalis (Cooke) Wint.], cedar apple rust (Gymnosporangium juniperi-virginianae Schwein.), and fire blight [Erwinia amylovora (Burr. Winslow et al.] indicated that more than $10 \%$ have resistance to one or more of the three diseases. Preliminary analysis indicates that the resistance to apple scab takes two forms and may represent novel variation. While potentially useful, finding these genes in material with better horticultural quality would be even more desirable. Discovery of new sources of resistance to scab would be timely, since Parisi et al. (1993) recently reported the appearance of a $V$. inaequalis race that is virulent to apple genotypes carrying the commonly deployed $\mathrm{V}_{\mathrm{f}}$ resistance gene derived from $M$. floribunda (Siebold) ex. Van Houte. In addition, resistance to cedar apple rust and fire blight found in this germplasm, which did not coevolve with these pathogens, may also represent new sources of resistance.

The material collected in 1989 and 1993 has also provided clues on how to most efficiently devise a collection strategy for Malus in the center of diversity. W. Lamboy of the PGRU and Norman Weeden, Cornell Univ., used isozyme analysis to determine levels of genetic variation present in the 1989 and 1993 collections of $M$. sieversii (Lamboy et al., 1996). Based on genetic analysis of sib families from four regions, the populations of $M$. sieversii surveyed appear to constitute a single panmictic population, with more than $85 \%$ of the total genetic variation due to differences among families and only $15 \%$ due to differences among regions. Thus, we determined that the most efficient strategy to acquire generalized genetic diversity and potentially useful alleles would be to explore as many unique ecological niches as possible.

The strategy appeared to work in the 1995 expedition, which was organized by P. Forsline and A. Djangaliev and included J. Luby and E. Tajikistan, and Kazakstan.
Dickson (Univ. of Calgary, Calgary, Canada) (Forsline, 1995). We were also joined by two South African scientists, Taaibos Human, apple breeder from INFRUTEC and Gary Britz, product development officer from UNIFRUCO Ltd., who will maintain their own germplasm collection.

Fruits were collected from four of the same sites collected in 1993 (Fig. 1B-E). Fortunately, fruit set was excellent, permitting better assessment of morphological variability. In addition, we visited a new site in the Tarbagatai region (Fig. 1A) at $47.5^{\circ} \mathrm{N}$-the northernmost range for $M$. sieversii and equivalent to the most northern areas of the 48 contiguous states in the United States. In addition to its potential cold hardiness, fruit quality was extraordinary (Fig. 2, Table 1). Some individual trees bore fruit nearly $70 \mathrm{~mm}$ in diameter with excellent aroma, firmness, and a predominance of pink to red skin (most $M$. sieversii seen up to this point had been green). Furthermore, spur-type trees were more prominent in this area compared to other sites. In a second newly explored site in the Karatau region (Fig. $1 \mathrm{~F}-\mathrm{G}$ ), a hot, arid area at $42^{\circ} \mathrm{N}$, trees had highly tenacious fruit of good horticultural quality.

We collected 60,000 seeds following two strategies. First, to provide material for genetic studies of population structure and diversity, we collected seed from 30 random trees representing 10 populations at diverse sites. Second, across all sites, trees with superior horticultural characteristics were sampled either by collecting seed (101 trees) or scionwood (14 trees) (Table 1). Scionwood is currently being processed at the USDA-ARS National Plant Germplasm Quarantine Center, Glenn Dale, Md. All collected material was documented by 25 horticultural descriptors and associated site information, and divided for ex situ preservation by A. Djangaliev's laboratory and the PGRU.

Seedlings from the 1995 populations are being germinated for several evaluations, including: screening for apple scab, cedar apple rust, and fire blight in $\mathrm{H}$. Aldwinckle's laboratory; resistance to apple maggot by Harvey Reissig, Dept. of Entomology, Cornell Univ.; and genetic analysis by $\mathrm{N}$. Weeden. Other cooperators are evaluating general horticultural qualities, including: J. Luby; Curt Rom, Dept. of Horticulture, Univ. of Arkansas, Fayetteville; Bruce Barritt, Fruit Tree Research Center, Washington State Univ., Wenatchee; and scientists in South Africa, Germany, and Japan, as well as at the PGRU.

We will be screening the same seedling populations with Simple Sequence Repeat (SSR) DNA markers (Szewc-McFadden etal., 1995), focusing on two population level genetic parameters: 1) the overall level of genetic diversity and 2) the degree of genetic structuring. The results should allow us to determine if the full range of genetic diversity is represented in our ex situ collection and to devise effective strategies for collecting germplasm and establishing in situ germplasm reserves. 


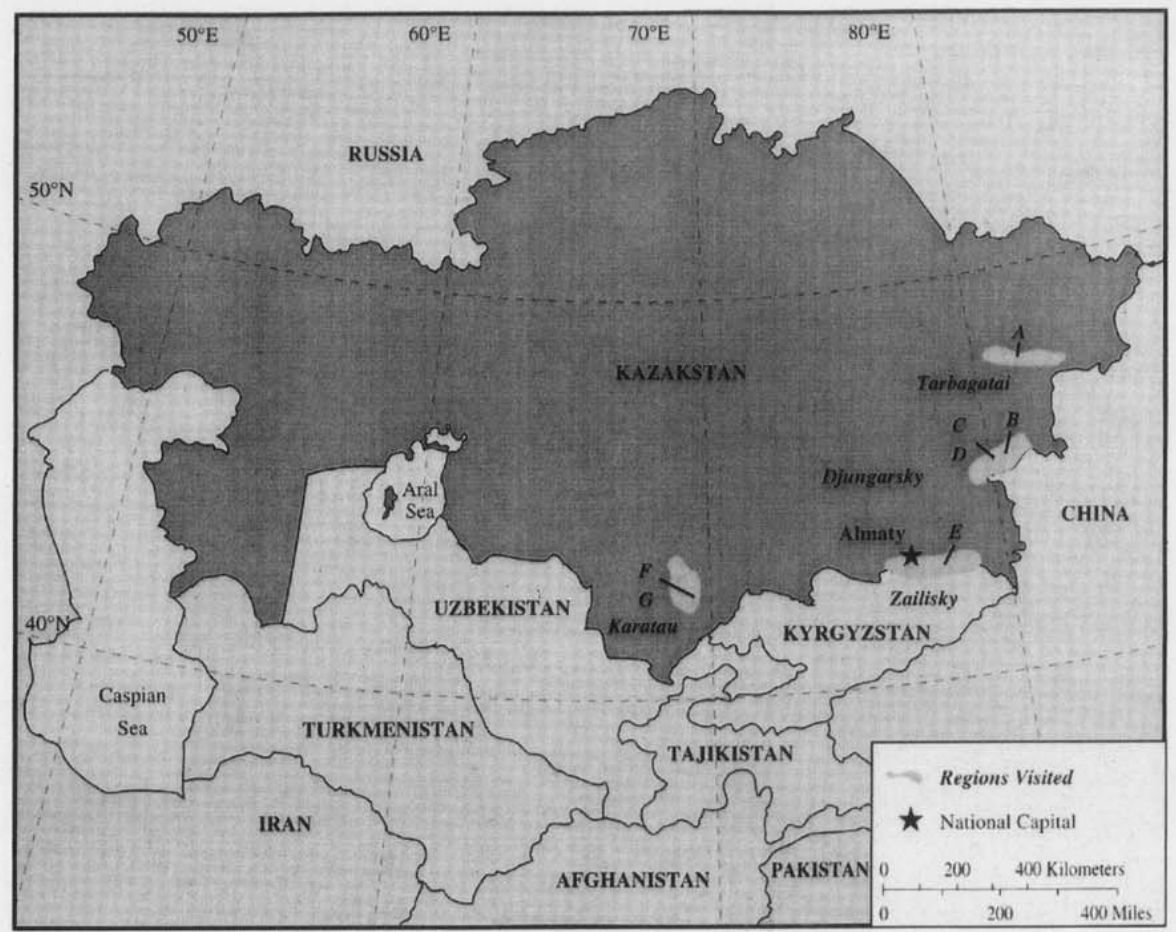

Fig. 1. Map depicting the Central Asian region where the Malus germplasm expeditions have been conducted. Collections have been made at seven sites in four regions in the Republic of Kazakstan: (A) Tarbagatai; (B, C, D) Djungarsky; (E) Zailisky; and (F, G) Karatau.

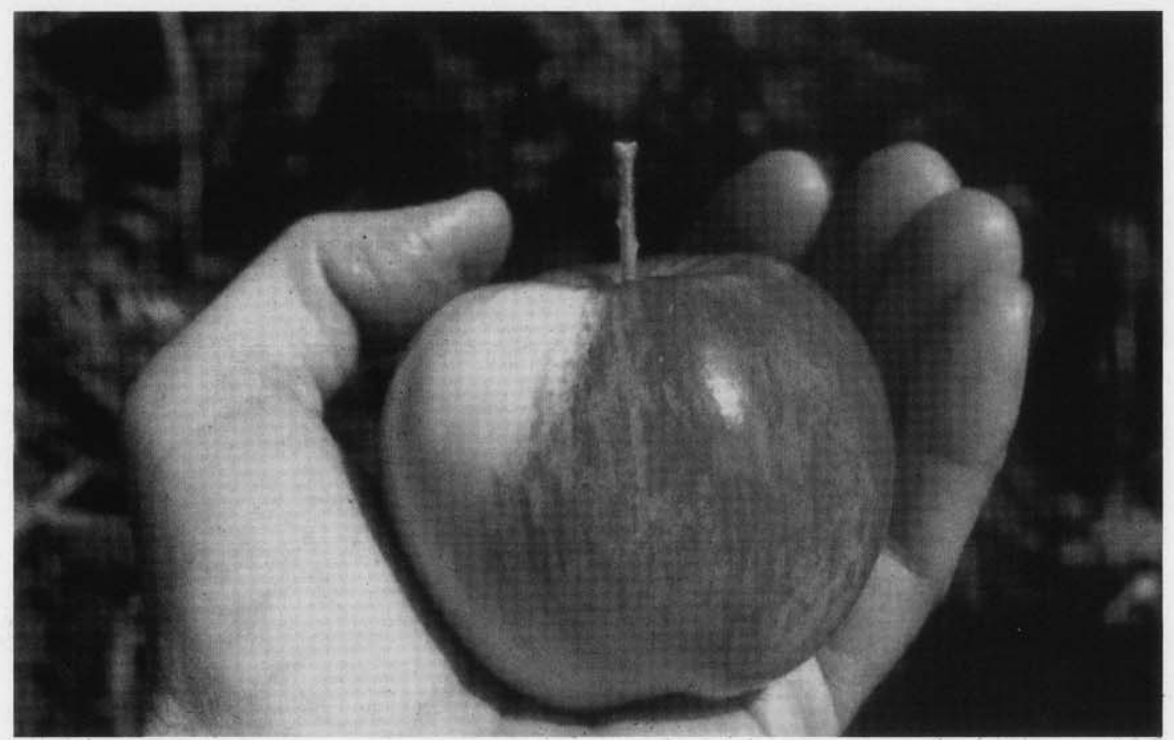

Fig. 2. High-quality apple fruit collected from one of the horticulturally superior trees discovered in the Tarbagatai region, Republic of Kazakstan.

\section{FUTURE DIRECTIONS FOR THE COLLABORATION}

Thirty-five years after V. Vitkovich described the region, much of the beauty and allure of the rugged landscape still exists. Magnificent, 300-year-old apple trees still dominate some mountainsides and bear tracks can still be seen on the ancient footpaths. However, today one can also see the unmistakable and expanding influence of human activity. The cloven prints of goats and sheep are mixed with the bear tracks. Openings have been rent in the ancient apple forests for vacation dachas. Like so many of the earth's bio- ately needed hard currency, many once-protected resources are being sold. In Kyrgyzstan, walnut (Juglans regia L.) forests estimated to cover 600,000 ha in 1930 , had been reduced to 48,000 ha in 1996 (G. McGranahan, 1996, pers. comm.) and nearly $85 \%$ of the wild apricot (Prunus armeniaca L.) forests that existed as recently as 1960 are now gone (T.N. Salova, 1996, pers. comm.). About $90 \%$ of the wild apple forests that existed near Almaty in 1935 are now gone. Regeneration of the remaining apple forests is prevented by the foraging of sheep and goats. Loss of these seedling generations prevents genetic recombination and also poses the risk of eliminating rare genes and genotypes.

One response to this fast developing crisis in the Malus center of diversity would be to collect a diversity of germplasm and bring it to a repository for characterization, documentation, and distribution. Ideally, this ex situ strategy should only be a component of a longterm germplasm management plan. Worldwide, ex situ collections are already at carrying capacity. Additions to NPGS collections must be made carefully, as maintaining large ex situ collections of long-lived perennials such as Malus is expensive ( $\$ 50.00$ to $\$ 75.00$ per accession/year). When new germplasm is added to the system, decisions have to be made about what will be eliminated to make room. Part of the response to these economic and logistical issues has involved the development of a cryogenic storage system for our clonal material (Stushnoff, 1991; Stushnoff and Seufferheld, 1995). The other component of a long-term management plan should involve in situ conservation. Many more diverse genotypes could be maintained in natural preserves at a much lower cost than would be possible in ex situ management. More importantly, maintaining wild germplasm in situ will allow for the continued evolution of resistances and adaptations (Frankel et al., 1995).

Material collected on the recent trips has already demonstrated the value of such wild germplasm for crop improvement. Political and social instability in Kazakstan has emphasized the precarious state of wild germplasm. A long-term goal of this project is to develop a cooperatively planned long term in situ conservation plan for Malus wild germplasm. Results from our research will allow us to focus our conservation efforts on populations and regions that contain the most genetic diversity.

Management of apple genetic resources has changed considerably since Johnny Appleseed crisscrossed the American frontier distributing germplasm out of a burlap bag. The process is now an international enterprise, challenged by such issues as environmental degradation, legal and political issues regarding germplasm ownership, and declining budgets. Simultaneously, the management of genetic resources is facilitated by the availability of new genetic tools and a worldwide infrastructure dedicated to their conservation and utilization. Despite the increased complexities of this management process, the ultimate goal refuses to be so complicated. As consum- 
Table 1. Fruit characteristics of wild Malus germplasm collected randomly ${ }^{z}$ or selected for superior horticultural type ${ }^{y}$ at seven divergent sites in Kazakstan in Sept. 1995.

\begin{tabular}{|c|c|c|c|c|c|c|c|c|c|c|}
\hline \multirow[b]{2}{*}{$\begin{array}{l}\text { Collection } \\
\text { region }\end{array}$} & \multirow[b]{2}{*}{$\begin{array}{l}\text { Map } \\
\text { site }^{x}\end{array}$} & \multirow[b]{2}{*}{$\begin{array}{c}\text { Elevation } \\
(\mathrm{m})\end{array}$} & \multicolumn{4}{|c|}{ Random populations } & \multicolumn{4}{|c|}{ Selected populations } \\
\hline & & & $\begin{array}{c}\text { Mean diam } \\
(\mathrm{mm})\end{array}$ & $\begin{array}{c}\text { Red fruit } \\
(\%)\end{array}$ & $\begin{array}{l}\text { Firm fruit } \\
(\%)\end{array}$ & $\begin{array}{l}\text { Aromatic } \\
\text { fruit }(\%)\end{array}$ & $\begin{array}{l}\text { Mean diam } \\
(\mathrm{mm})\end{array}$ & $\begin{array}{l}\text { Red fruit } \\
(\%)\end{array}$ & $\begin{array}{c}\text { Firm fruit } \\
(\%)\end{array}$ & $\begin{array}{r}\text { Aromatic } \\
\text { fruit (\%) } \\
\end{array}$ \\
\hline Targabatai & $\mathrm{A}$ & $870-1120$ & 43 & 61 & 40 & 29 & 56 & 96 & 67. & 84 \\
\hline Djungarsky & B & $1190-1360$ & 34 & 27 & 0 & 3 & 37 & 50 & 63 & 25 \\
\hline Djungarsky & $\mathrm{C}$ & $1170-1450$ & 36 & 33 & 3 & 17 & 46 & 80 & 90 & 50 \\
\hline Djungarsky & D & $1450-1690$ & 35 & 50 & 57 & 10 & 38 & 50 & 50 & 50 \\
\hline Zailisky & $\mathrm{E}$ & $1360-1550$ & 34 & 33 & 15 & 12 & 45 & 91 & 27 & 27 \\
\hline Karatau & $\mathrm{F}$ & 600 & 41 & 30 & 10 & 23 & 39 & 50 & 67 & 17 \\
\hline Karatau & G & 900 & 41 & 62 & 44 & 44 & 42 & 80 & 90 & 60 \\
\hline
\end{tabular}

${ }^{2}$ Thirty trees were randomly selected in each population and five to eight fruit were sampled per tree.

${ }^{y}$ A variable number of trees were selected in each population based on fruit size, color, and aroma and 30 to 150 fruit were sampled per tree.

${ }^{x}$ See Fig. 1.

ers, we want what our predecessors wanteda crisp, flavorful apple in our jacket pocket, a cool glass of tangy cider, and a piece of that hot, golden-crusted apple pie.

\section{Literature Cited}

Brooks, H.J. and D.W. Barton. 1977. A plan for national fruit and nut germplasm repositories. HortScience 12:298-300.

Brooks, H.J. and G. Vest. 1985. Public programs on genetics and breeding of horticultural crops in the United States. HortScience 20:826-830.

Brown, A.H.D. and D.R. Marshall. 1995. A basic sampling strategy: theory and practice, p. 7591. In: L. Guarino, V.R. Rao, and R. Reid (eds.). Collecting plant genetic diversity. CAB Intl., Wallingford, U.K.

Dinerstein, E., V. Krever, D.M. Olson, and L. Williams. 1994. An emergency strategy to rescue Russia's biological diversity. Conserv. Biol. 8:934-942.

Djangaliev, A.D. 1977. The wild apple tree of Kazakstan (in Russian). Nauka Publishing House, Almaty, Kazakstan.

Epperson, B.K. 1990. Spatial patterns of genetic variation within plant populations, p. 229-253. In: A.H.D. Brown, M.T. Clegg, A.L. Kahler, and B.S. Weir (eds.). Plant population genetics, breeding, and genetic resources. Sinauer, Sunderland, Mass.

Food and Agriculture Organization. 1996. FAOSTAT database collections. Rome, Italy. http://apps.fao.org/cgi-bin/aphdb.pl?subset=agriculture

Forsline, P.L. 1995. Adding diversity to the national apple germplasm collection: Collecting wild apple in Kazakhstan. New York Fruit Quart. $3: 3-6$.

Forsline, P.L. and R.D. Way. 1993. Apple accessions of low priority targeted for removal from the National Plant Germplasm System. Fruit Var. J. 47:204-214.

Frankel, O.H., A.H.D. Brown, and J.J. Burdon. 1995. The conservation of plant biodiversity. Cambridge Univ. Press, Cambridge, U.K.

Janick, J., J.N Cummins, S.K. Brown, and M. Hemmat. 1996. Apples, p. 1-76. In; J. Janick and J.N. Moore (eds.), Fruit breeding. vol. II. Tree and tropical fruits. Wiley, New York.

Korban, S.S. 1986. Interspecific hybridization in Malus. HortScience 21:41-48.

Lamboy, W.F., J. Yu, P.L. Forsline, and N.F. Weeden. 1996. Partitioning of isozyme diversity in wild populations of Malus sieversii L. and implications for germplasm collection. J. Amer. Soc. Hort. Sci. 121:982-987.
Morgan, J. and A. Richards. 1993. The book of apples. Ebury Press, London, U.K.

Parisi, L., Y. Lespinasse, J. Guillaumes, and J. Krüger. 1993. A new race of Venturia inaequalis virulent to apples with resistance due to the $\mathrm{Vf}$ gene. Phytopathology 83:533-537.

Stushnoff, C. 1991. Cryopreservation of fruit crop genetic resources-Implications for maintenance and diversity during conservation. HortScience 26:518-522.

Stushnoff, C. and M. Seufferheld. 1995. Cryopreservation of apple (Malus species) genetic resources, p. 87-101. In: Y.P.S. Bajaj (ed.). Biotechnology in agriculture and forestry. vol. 32. Cryopreservation of plant germplasm I. Springer-Verlag, Berlin.

Szewc-McFadden, A.K., S. Bliek, C.G. Alpha, W.F. Lamboy, and J.R. McFerson. 1995. Identification of simple sequence repeats in Malus (apple). HortScience 30:855

Vavilov, N.I. 1987. Five continents (in Russian). Mysl Publishers, Moscow.

Way, R.D., H.S.Aldwinckle, R.C.Lamb, A. Rejman, S. Sansavini, T. Shen, R. Watkins, M.N. Westwood, and Y. Yoshida. 1991. Apples (Malus), p. 3-62. In: J.N. Moore and J.R. Ballington (eds.). Genetic resources of temperate fruit and nut crops 1 . Intl. Soc. Hort. Sci. Wageningen, Netherlands. 